\title{
手のひらサイズの超小型広視野フーリエ分光イメージング技術
}

鈴木 陽 $^{1}$, 斉 威 ${ }^{1}$, 佐藤 駿 ${ }^{1}$ ，藤原 大 $^{1}$ ，平松 裕行 $^{1}$ ，川嶋なつみ ${ }^{1}$, 鈴木 聡 $^{1}$, Pradeep ABEYGUNAWARDHANA ${ }^{1}$ ，和田 健司 ${ }^{2}$ ，西山 成 ${ }^{2}$ ，小林 宏明 ${ }^{3}$ ，石丸 伊知郎 ${ }^{1}$

1香川大学工学部 ( ₹761-0396 香川県高松市林町2217-20)

2香川大学 医学部 ( ₹761-0793 香川県木田郡三木町池戸1750-1)

3香川県産業技術センターシステム技術部門（テ761-8031 香川県高松市郷東町587-1）

\section{Palm-Size Ultra-Compact Wide-Field Fourier Spectroscopic Imaging Technology}

\author{
Yo SUZUKI, ${ }^{1}$ Wei QI, ${ }^{1}$ Shun SATO, ${ }^{1}$ Masaru FUJIWARA, ${ }^{1}$ Hiroyuki HIRAMATSU, ${ }^{1}$ \\ Natsumi KAWASHIMA, ${ }^{1}$ Satoru SUZUKI, ${ }^{1}$ Pradeep ABEYGUNAWARDHANA, ${ }^{1}$ Kenji WADA, ${ }^{2}$ \\ Akira NISHIYAMA, ${ }^{2}$ Hiroaki KOBAYASHI, ${ }^{3}$ and Ichiro ISHIMARU ${ }^{1}$ \\ ${ }^{1}$ Faculty of Engineering, Kagawa University, 2217-20 Hayashi-cho, Takamatsu, Kagawa-pref., 761-0396 \\ ${ }^{2}$ Faculty of Medicine, Kagawa University, 1750-1 Ikenobe, Miki-cho, Kita, Kagawa-pref., 761-0793
}

${ }^{3}$ System Application Technology Branch, Kagawa Prefectural Industrial Technology Center 587-1 Goto-cho, Takamatsu, Kagawa 761-8031

(Received December 24, 2014)

\begin{abstract}
We realized the palm-size (Dimension: L56 mm $\times$ W69 $\mathrm{mm} \times \mathrm{H} 43 \mathrm{~mm}$, Weight: $500 \mathrm{~g}$ ) wide-field spectroscopic imager based on the proposed imaging-type 2-dimensional Fourier spectroscopy. We installed the variable phase-filter at optical Fourier transform plane of infinity corrected optical systems. Because of the wavefront-division-type phase-shift-interferometer, the proposed near-common-path interferometer between objective beams has strong robustness for mechanical vibrations. But destructive interference phenomena in accordance with phase-shift value were occurred between adjacent singlebright points. To improve visibilities especially for low spatial frequencies of wide-field mid-infrared images, we also proposed the conjugate-plane multi-slit superimpose method for thinning out adjacent single-bright points. Thereby, we could demonstrate the omnidirectional spectroscopic imaging with 50-degree view angle by a hyperboloidal mirror. In this paper, we clarified the optical phenomenon that results in phase-shift destructions between adjacent single-bright points. And then, we demonstrated feasibilities of wide-field spectroscopic imaging in visible and mid-infrared light region.
\end{abstract}

Key Words: Fourier spectroscopy, Spectroscopic imaging, Wide-field, Middle infrared light, Nearcommon-path phase-shift interferometer

\section{1.はじめに}

近年，小型無人航空機に高機能カメラを搭載して，危 険地区の監視や局所的な環境管理を行う需要が増えつつ ある。また，世界的な健康意識の高まりから，分光技術 を用いたへルスケア機器開発の研究が行われている。そ して，これらの技術を実現するために，広視野を高感度 に計測可能であり，かつ小型低価格の分光装置が求めら れている. 従来, 分光イメージング計測にはAOTF (Acousto-Optic Tunable Filter) 型や分散型のハイパースペ クトルカメラや, イメージングFTIR (Fourier transform infrared spectroscopy) が用いられている。 また, 分光断 層イメージング手法として, 分光OCT (Optical coherence tomography) 技術の研究が行われている。しかし，八イ パースペクトルカメラは, 光の利用効率が低く, 多成分 計測が可能な中赤外光領域に適用できない，また，画角 による計測精度劣化を生じるため, 視野角が10 deg.程度
に限定されてしまう1)。一方，イメージングFTIRは，機 械振動に対するロバスト性が低く除振機構が必須であ る. 除振機構を装置内部に組み込んだFTIR型ハイパー スペクトルカメラもあるが装置価格が 1 億円以上，装置 重量 $29 \mathrm{~kg}$ である ${ }^{2}$. 分光OCT技術は，薄膜干涉と分光情 報との切り分けが困難であるため, コヒーレンス長より

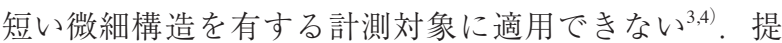
案する結像型2次元フーリエ分光法は准共通光路型位相 シフト干渉計であり，機械振動に対して高いロバスト性 を有した小型分光イメージング装置が実現可能であ る ${ }^{5)}$. 更に，6自由度の幾何モデルに基づく各光線に実 効的に与えられる位相シフト量の画角補正モデルを提案 することにより，広視野分光イメージングが可能となっ た ${ }^{7)}$. しかし，提案手法が波面分割型の位相シフト干渉計 であることから，隣り合う輝点間での位相打ち消し現象 が発生することが判明した。これは，特に中赤外光など の空間周波数の低い画像での広視野計測時に，高い干渉 


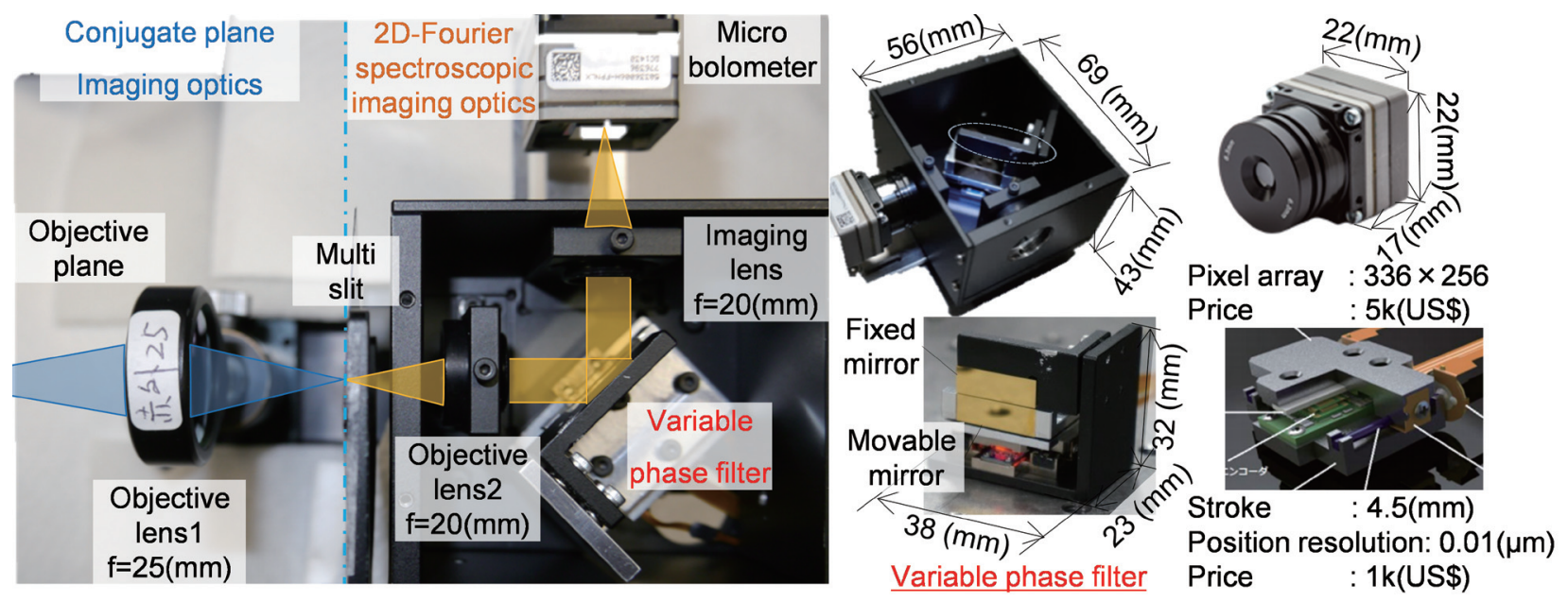

Fig. 1 Palm-top size (Dimension: L56 [mm] $\times$ W69 [mm] $\times$ H43 [mm], Weight: $500[\mathrm{~g}]$ ) Fourier spectroscopic imaging apparatus.

鮮明度での高感度分光測定で問題となる。そこで，隣り 合う輝点を光学的に間引く共役面多重スリット重畳法を 提案する. また, 視野角 $50 \mathrm{deg}$.の双曲面ミラーによる全 方位分光イメージングと, 中赤外光領域 $(\lambda=8 \sim 14 \mu \mathrm{m})$ の輻射光による全顔分光イメージング計測の実現可能性 の実証実験を行った。

\section{2. 結像型2次元フーリエ分光法 ${ }^{5,6)}$}

\section{1 波面分割型物体光間位相シフト干渉計}

提案手法の原理をフーリエ変換光学の観点から説明す る。提案手法は, 無限遠補正結像光学系のフーリエ変換 面上に光束の半分に対して任意の位相差を与える位相可 変フィルタを導入した物体光間位相シフト干渉計であ る。位相可変フィルタは2つのミラー面で構成しており, 一方は高精度なピエゾ素子によって動作可能な可動ミ ラー部，もう一方は固定ミラー部である。この時，フー リ工変換面で与えられる波長毎の位相差 $\theta$ について考慮 すると, 式(1)のように表すことができる.

$$
\theta(\lambda)=\frac{2 \pi \delta}{\lambda}
$$

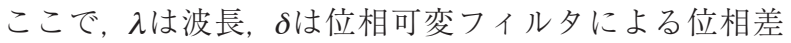
を示す。ささに, すべての波長について考えると, 他波 長における結像複素振幅分布は, 式(2)のように表すこ とができる。

$$
\begin{aligned}
f^{\prime}\left(x_{0}, y_{0}\right)= & \iiint_{-\infty}^{\infty} F^{\prime}\left(x_{f}, y_{f}, \lambda\right) \\
& \times e^{-i\left\{2 \pi\left(x_{f} x_{0}+y_{f} y_{0}\right)+\phi\left(x_{f} y_{f}\right)\right\}} d x_{f} d y_{f} d \lambda
\end{aligned}
$$

ここで， $x_{0}, y_{0}$ は結像面上の空間座標， $x_{f}, y_{f}$ はフーリエ 変換面上の空間座標, $\mathrm{F}^{\prime}\left(x_{f}, y_{f}, \lambda\right)$ は各波長における回 折光分布, $\phi\left(x_{f}, y_{f}\right)$ は位相分布を示す. 光路差 $\delta$ の変化 に伴って位相差 $\theta(\lambda)$ が連続的に変化する場合, 輝点の 強度変化は, 初期位相が等しく周期の異なる波の足し合 わせととらえることができる。このとき，観察される強 度変化は, 白色光のインターフェログラムと同意であ

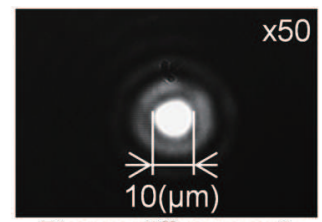

Phase difference: 0
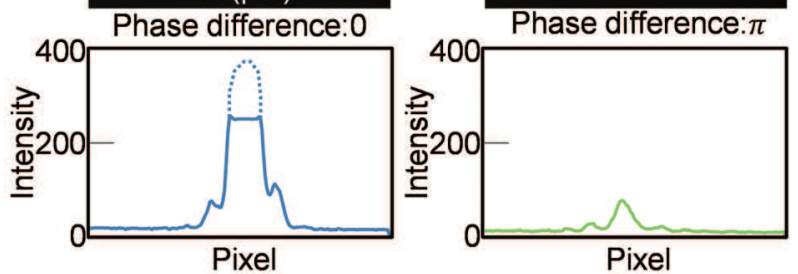

Fig. 2 Brightness-distribution changes with phase-shift operation in the case of Michelson interferometer.

り，通常のフーリエ分光法と同じ数学的処理によりスぺ クトル解析が行える。この処理を面内全ての輝点に対し て行うことで分光イメージング計測が行える．また，提 案手法は 1 つ輝点から発せられた光線間で干渉現象を 生じさせるので，輻射光のような空間的インコヒーレン ト光にも適用可能である

\section{2 低価格超小型中赤外分光イメージング装置}

提案手法は, Fig. 1左に示すよう光学系に共役面結像 光学系と結像型2次元フーリエ分光光学系の 2 つ光学系 で構成している。共役面結像光学系は, 計測対象の共役 像を分光光学系の物体面上に結像させている。 その際, 計測対象に応じて光学倍率を自由に選択することができ る. そして, 結像型2次元フーリエ分光光学系によって 分光イメージング計測を行う。この時，光学倍率を等倍 にして構築し，レンズと位相可変フィルタ間の距離を限 界まで近づけることで光学系をさらに小型化できる。ま た結像型2次元フーリエ分光光学系は, 共役面結像光学 系と独立して設計可能なので, 共通ユニット化すること ができる.Fig. 1に実際に構築した手のひらサイズ分光 イメージング装置を示す。最近発売された低価格な小型 マイクロボロメータやノートパソコンで駆動可能なイン パクト駆動アクチュエータを導入することで低価格かつ 超小型分光イメージング装置が実現できた。 


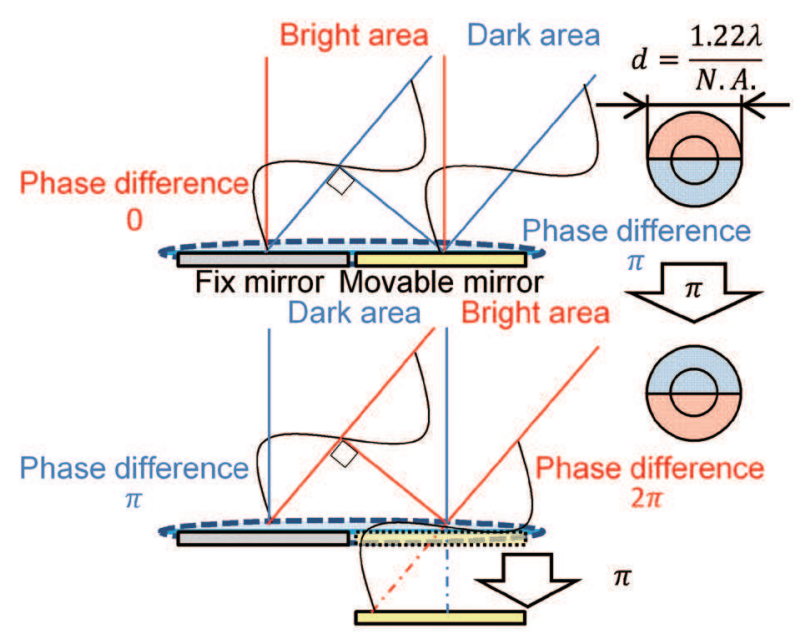

Fig. 3 Phase-shift distribution within single bright-points.
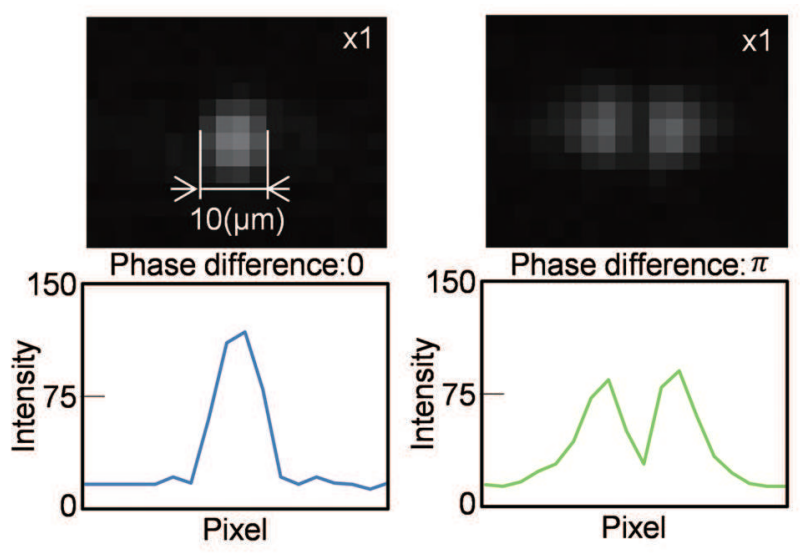

Fig. 4 Brightness distribution changes with phase shift operation in the case of the proposed method.

\section{3 隣り合う輝点間での干渉強度打ち消し現象}

波面分割型位相シフト干渉計とマイケルソン干渉計に 代表される振幅分割型では，位相シフトに伴うエアリー パターン内部の干渉強度分布変化が異なる。物体面上の 輝点は結像面において, 式(3)の直径 $d$ のエアリーディス クとして像を形成する。

$$
d=\frac{1.22 \lambda}{N \cdot A}
$$

ここで, Numerical Aperture(N.A.) はレンズの数值開口数 を示す。この時, 輝点に対して位相差 $0, \pi$ 与える。

Fig. 2に振幅分割型干渉計であるマイケルソン干渉計を 用いた実験結果を示す。今回，位相シフト操作に伴う第 一暗輪帯の強度変化の様子が観察できるように感度を調 節しているため, 0 次光部分は信号強度が飽和してし まっている，そこで，0次光部部分の信号強度予想線を 破線で示す。この時, 第一暗輪帯は強度変化を示さず, 中央の 0 次光のみが明暗変化を繰り返すような干渉強度 変化が確認できた。次に，提案手法の場合について，ま ずFig. 3に示す輝点の干渉強度変化に伴う輝度分布変化 モデルを用いて考えた。今回使用した位相可変フィルタ は異方性があり, 縦横一方向のみに干渉強度変化が生じ る. 初期状態の場合, 0 次光を形成する光線は, 位相差 0

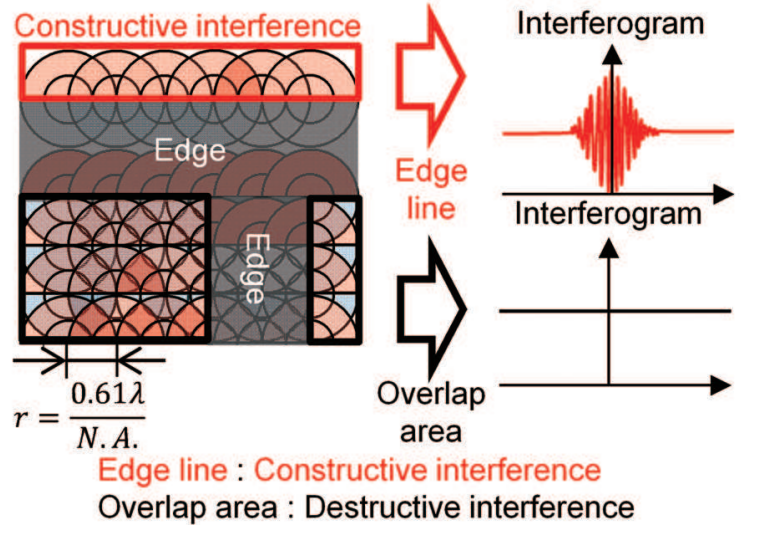

Fig. 5 Destructive interference optical model between bright points of wavefront-type phase-shift interferometer.
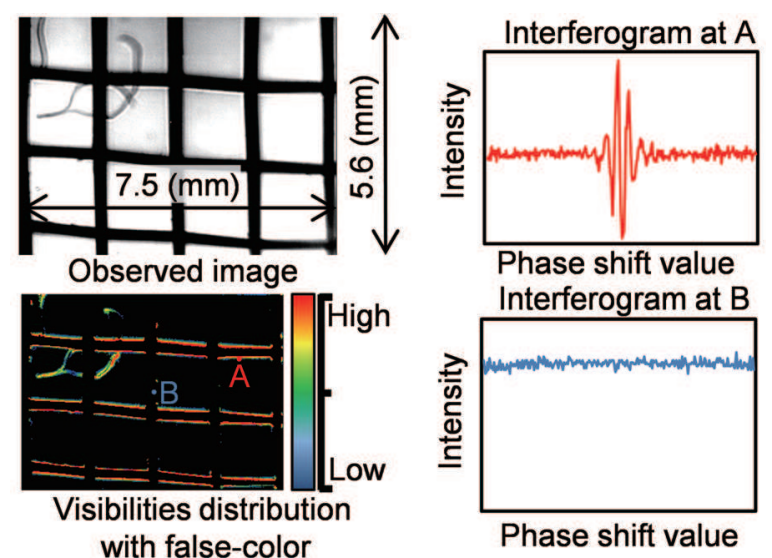

Fig. 6 Constructive interference phenomena were occurred at only horizontal edge-Iine.

のため明るい像を形成し，第一暗輪帯を形成する光線 は，位相差 $\pi$ のため暗い像を形成する。次に，位相可変

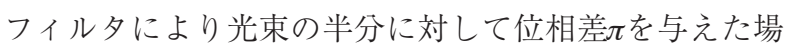
合，0次光を形成していた光線は，位相差がオになるた め暗い像を形成し，第一暗輪帯を形成していた光線は, 位相差が $2 \pi$ となり明るい像を形成する。このように， 0 次光と第一暗輪帯の強度が入れ替わるような干渉強度変 化を示すと考えられる．Fig. 4に実際に提案手法を用い て輝点に位相シフト操作を行った結果を示す。予想通り 横方向に対して，0次光と第一暗輪帯で強度が入れ替わ るような干渉強度変化を確認できた。, 次に, 提案手法固 有の干渉強度変化によって生じる, 隣り合う輝点間での 干渉強度打ち消し現象について説明する。物体面上の輝 点群は, 結像面上においてレイリーの判断基準に基づい て，エアリーディスクが式(4)の間隔で結像していると モデル化できる.

$$
r=\frac{0.61 \lambda}{N \cdot A .}
$$

Fig. 5に結像面上の輝点群モデルを示す。この時, 隣り 合う輝点が存在しないエッジ部と, 隣り合う輝点が重な り合っている領域の2つについて考える. 全ての輝点に 対して同時に位相シフト操作を行った場合，干渉強度変 化に対して水平なエッジ部では隣り合う輝点がないため 

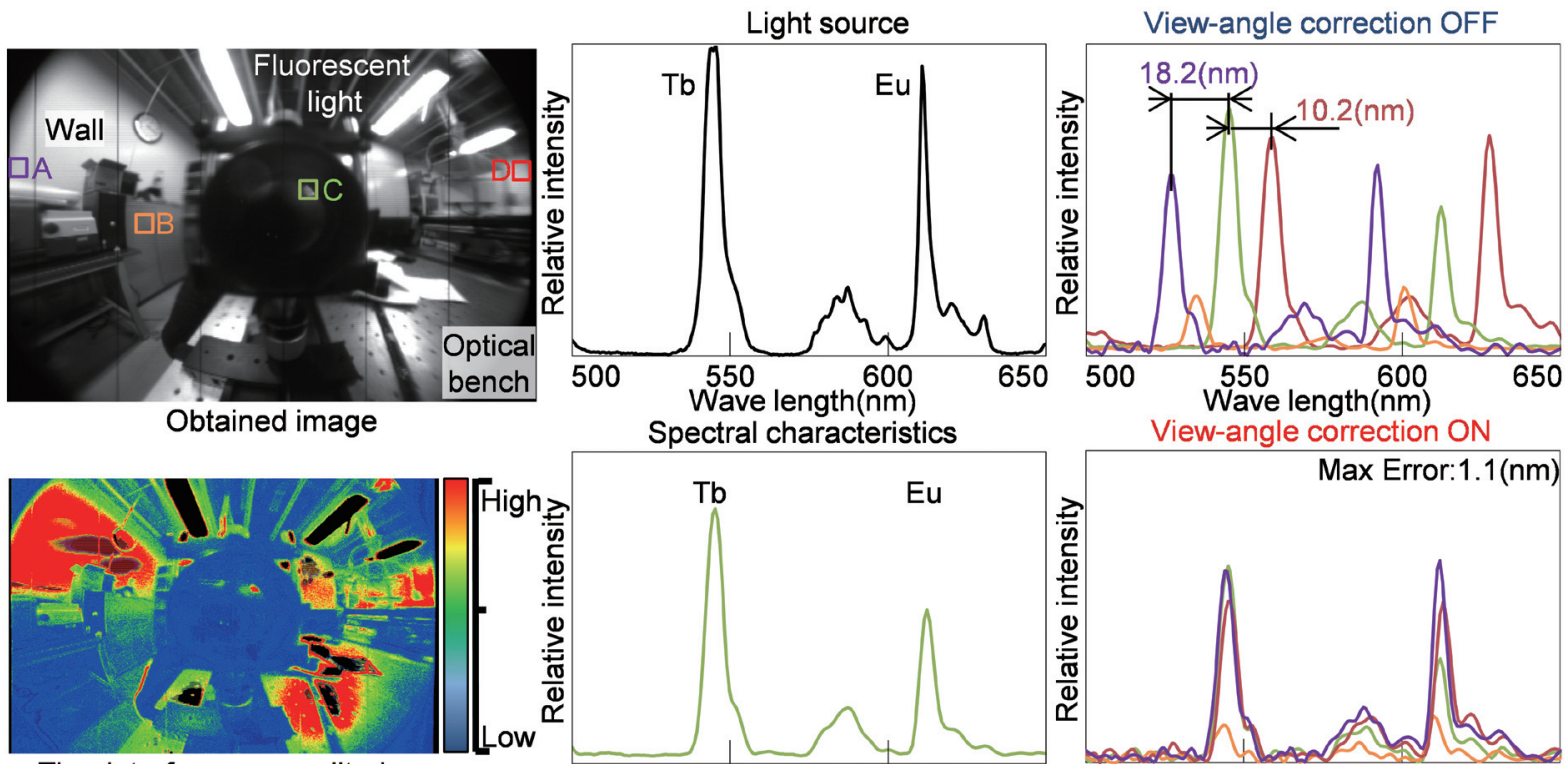

The interference amplitude distribution map
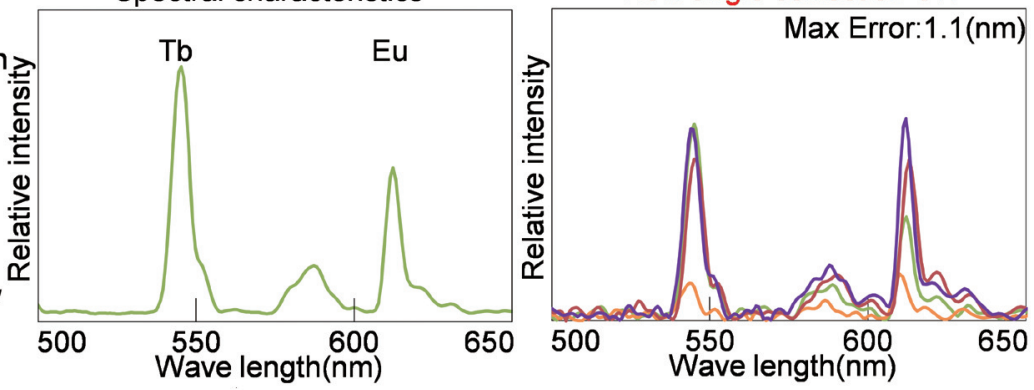

Fig. 7 Measurement results of omnidirectional spectroscopic imaging with view-angle correction method.

干渉強度変化が発生し, インターフェログラムが取得で きるのに対して，それ以外の領域では，隣り合う輝点の 0 次光と第一暗輪帯が互いに重なり合い, 常に同じの輝 度值のまま維持してしまう。つまり，位相差を与えて も, 水平エッジ部以外では干渉強度変化が打ち消されて しまい, インターフェログラムが取得できなくなってし まう. Fig. 6に示すように, 開口幅 $1.5 \mathrm{~mm}$, 遮光幅 $0.3 \mathrm{~mm}$ 金網を設置した場合, 水平エッジ部A点のみで 鮮明度の高いインターフェログラムが確認できた。垂直 エッジ部B点では位相シフターの異方性により, 干渉強 度打ち消し現象が発生し, インターフェログラムを取得 できていない，そこで, 新たに共役面結像光学系の結像 面上に多重スリットを設置し隣り合う輝点を間引くこと で打ち消し現象を除去する共役面多重スリット重畳法を 提案する.これにより, 光学倍率に依存することなく分 光イメージング計測が可能になった。 なお，今回使用す る多重スリットは実験時に最も高い鮮明度の干涉強度変 化が得られたものを用いている。

\section{3. 可視光全方位分光イメージング計測}

\section{1 双曲面ミラーによる可視光全方位分光光学系}

本光学系は, 双曲面ミラー(メーカー：映蔵, 型式 : Hyper70, 仰角 : $30 \mathrm{deg}$, 俯角 : $50 \mathrm{deg}$ )の全領域が多重 スリット上に投影されるように, 共役面結像光学系の対 物レンズ1には, $f=50 \mathrm{~mm}, \phi=35 \mathrm{~mm}$ のBK7レンズを使 用し, レンズ光学倍率を 0.15 倍とした。 また, 結像型2 次元フーリエ分光光学系には, 対物レンズ2, 結像レン ズに $f=100 \mathrm{~mm}, \phi=35 \mathrm{~mm}$ のBK7レンズを使用し, 受光 デバイスには白黒カメラモジュール(メーカー：SONY, 型式: XC-51, 画素ピッチ: $8.4 \times 9.6 \mu \mathrm{m}$, 画素数 : $768 \times 494$ pixels, フレームレート : $30 \mathrm{~Hz}$, 計測波長帯 域：400〜800 nm) を使用した。多重スリットは，開口

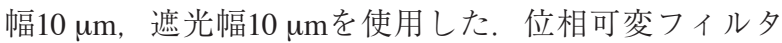
は, ピエゾステージ(メーカー：PI, 型式：P-622, 分解

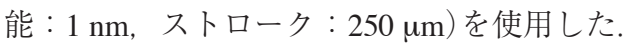

\section{2 可視光全方位分光イメージング計測結果}

本実験は，実験室内の風景を観察し分光イメージング 計測を行った。この際, 構造的な照明は行わず蛍光灯の 光のみで計測を行っている。本実験の計測条件は, サン プリング間隔 $91 \mathrm{~nm}$, 位相シフト量 $110 \mu \mathrm{m}$, 波長分解能 $2.75 \mathrm{~nm}$ である。Fig. 7左に観察画像及び干渉強度分布可 視化画像を示す。観察像全体において干渉強度变化が生 じていることを確認した，特に，反射率の高い壁や光学 定盤において高い干渉強度変化を得ていることが確認で きた。 なお，蛍光灯や光学定盤の一部において干渉強度 変化が取得できていないのはサチレーションが発生した ためである. Fig.7中央に光源である蛍光灯と観察像内C 点の分光特性を比較した結果を示す.C点で取得した分 光特性において蛍光物質Terbium $(\mathrm{Tb})$ とEuropium $(\mathrm{Eu})$ が 有している波長 $540 \mathrm{~nm}$ と $620 \mathrm{~nm}$ の輝線スペクトルを取 得できていることを確認した。従って，構造的な照明が 不要な全方位分光イメージング計測の実現可能性を実証 した。

\section{3 画角補正法による分光特性改善結果}

提案手法において，広視野分光イメージング計測を行 う場合，画角に応じて1フレーム間の位相シフト量が変 化してしまい，分光特性が劣化してしまう。そこで，新 たに式(5)の画角補正式を導入し，画角の違いによる分 光特性劣化を除去する ${ }^{7)}$.

$$
L=\frac{\left\{2 M \cos \left(\phi_{y}-\theta_{y}\right)\right\}}{\cos \left(\theta_{x}\right)}
$$

ここで, Mは1フレーム間の位相シフト量 $[\mu \mathrm{m}], \phi_{y}$ は位 
相可変フィルタの設置角 $\left[^{\circ}\right], \theta_{y}$ と $\theta_{x}$ はそれぞれ横軸方 向, 縦軸方向の画角 $\left[^{\circ}\right]$ を示す. Fig. 7右に観察像内A, $\mathrm{B}, \mathrm{C}, \mathrm{D}$ 点の分光特性について画角補正を行わなかっ た場合と，画角補正を行った場合の比較結果を示す。画 角補正を行わなかった場合，画角による分光特性劣化が 生じ, 最も画角が大きいA点-C点間で $18.2 \mathrm{~nm}$, 次点で 大きいC点-D点間で $10.2 \mathrm{~nm}$ の波長軸方向へのズレが生 じてしまっている。一方, 画角補正を行った場合, 全て の点において画角の違いによる分光特性劣化が補正され ており，分光特性を最大誤差 $1.1 \mathrm{~nm}$ で抑えて取得する ことができた。これは，波長分解能 $2.75 \mathrm{~nm}$ よも小さ い誤差に収まっており，十分な補正効果があったといえ る. 以上より, 画角補正法による分光特性改善効果を確 認し, 高精度全方位分光イメージング計測の実現可能性 を実証した。

\section{4. 中赤外広視野分光イメージング計測}

\section{1 体温から発する輻射光の中赤外分光光学系}

本光学系は, 人の顔全体が共役面上に結像するよう共

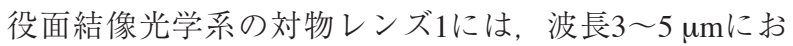
ける透過効率が高くなるように無反射 $(\mathrm{AR})$ コートを施 した $f=25 \mathrm{~mm}, \phi=25 \mathrm{~mm}$ のゲルマニウム $(\mathrm{Ge})$ レンズを 使用し、レンズ光学倍率を0.025倍とした。また, 結像 型2次元フーリエ分光光学系には対物レンズ 2 , 結像レン ズにARコートを施した $f=100 \mathrm{~mm}, \phi=50 \mathrm{~mm}$ のeレン ズを使用し，レンズ光学倍率を等倍とした。受光デバイ スには冷却型インジウムアンチモンカメラ (メーカー： 日本アビオニクス株式会社, 型式：TVS-8500画素ピッ チ : $30 \times 30 \mu \mathrm{m}$, 画素数: $256 \times 236$ pixels, フレーム レート：30 Hz，計測波長带域：3.5 4.1 $\mu \mathrm{m}, 4.5 \sim$ $5.1 \mu \mathrm{m})$ を使用した。多重スリットは, 開口幅51 um, 遮 光幅34 $\mu \mathrm{m}$ を使用した。 位相可変フィルタには, ピエゾ ステージ (メーカー : PI, 型式 : P-629, 分解能 : $10 \mathrm{~nm}$, ストローク： $1500 \mu \mathrm{m})$ を使用した。

\section{2 輻射光による全顔分光イメージング計測}

本実験では，計測時に構造的な照明を一切行わず，体 温程度の輻射光のみを用いて全顔分光イメージング計測 を行った。本実験の計測条件は。サンプリング間隔 $707 \mathrm{~nm}$, 位相シフト量 $1060 \mu \mathrm{m}$, 波長分解能 $19 \mathrm{~nm}$ であ る. Fig. 8に観察画像と干涉強度分布可視化画像を示 す。顔全体において高い鮮明度の干渉強度変化を得てい ることが分かる. Fig. 8中A点より取得した分光特性と, 3つの波長帯域に扔ける分光特性強度分布可視化画像を 示す。まず, A点より取得した分光特性から, 受光デバ イスの計測波長帯域と同じ波長3.5 4.1 $\mu \mathrm{m}, 4.5 \sim$ $5.1 \mu \mathrm{m}$ にプランクの法則に則った相対強度分布を得られ ていることを確認した. 次に, 分光特性強度分布可視化 画像から，3つの異なる波長帯域において, 顔全体で均 一な相対強度分布変化を取得していることを確認した。 以上により，構造的な照明を必要とせず，体温程度の輻 射光のみを用いた全顔分光イメージング計測の実現可能
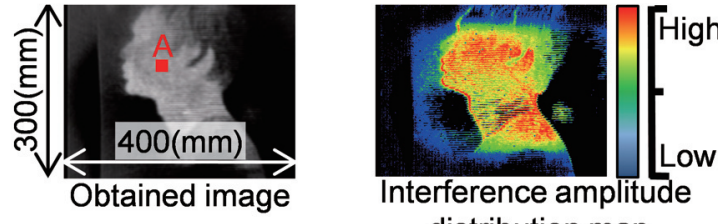

distribution map

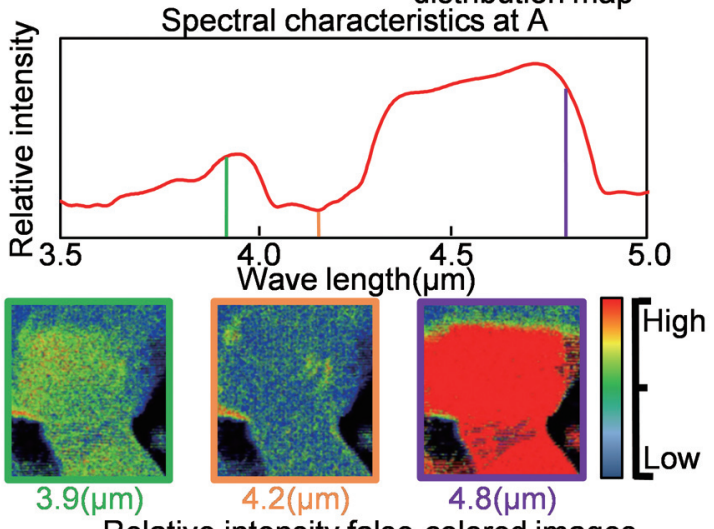

Relative intensity false-colored images

Fig. 8 Measurement results of whole-face spectroscopic imaging by radiation lights.

性を実証した。

5. まとめ

提案手法が波面分割型位相シフト干渉計であることか ら生じる, 隣り合う輝点間での干渉強度打ち消し現象を 明確にし，新たに共役面多重スリット重畳法を提案し た。これにより，双曲面ミラーを用いた可視光全方位光 学系を構築し, 超広視野分光イメージングの実現可能性 を実証した。また更に，体温から発生する輻射光の中赤 外広視野分光イメージングの実現可能性を実証した。

今後は, 干涉鮮明度を面内で均一に得られる最適多重 スリット形状の設計手法を確立する。

謝 辞

この開発は。(独)科学技術振興機構 研究成果展開事 業「先端計測分析技術・機器開発プログラム」による成果 である。また，多重スリットの製作は，アオイ電子(株) 筒井靖之氏にご協力頂いた。 深く感謝の意を表す.

\section{参考文献}

1) J. Katrašnik, F. Pernuš and B. Likar: Proc. SPIE 7556 (2010).

2) J. Allard, M. Chamberland, V. Farley, F. Marcotte, M. Rolland, et al.: Proc. SPIE 6954 (2008).

3) U. Morgner, W. Drexler, F. X. Kärtner, X. D. Li, C. Pitris, E. P. Ippen, and J. G. Fujimoto, Opt. Lett. 25 (2000) 111.

4）藤岡良太, 藤田昌也, 末国雅行, 神成文彦：レーザー研 究 31 (2003) 668.

5) Y. Inoue, I. Ishimaru, T. Yasokawa, K. Ishizaki, M. Yoshida, M. Kondo, S. Kuriyama, T. Masaki, S. Nakai, K. Takegawa, et al.: Appl. Phys. Lett. 89 (2006) 121103.

6) 小林宏明, 河尻武士, 矢野川果奈, 西山成, 田中直孝, 高橋 悟, 石丸 伊知郎: 光学 41 (2012) 36.

7) A. Inui, R. Tsutsumi, W. Qi, T. Takuma, H. KAGIYAMA D. Kojima, I. Ishimaru: Phys. Procedia 19 (2011) 61. 